\title{
TECHNOLOGY-HUMAN SECURITY NEXUS: CHALLENGES AND OPPORTUNITIES
}

\author{
Bülent Sarper Ağir ${ }^{\star}$, Associate Professor \\ Aydýn Adnan Menderes University, Aydýn Faculty of Economics
}

bsagir@adu.edu.tr 



\title{
TECHNOLOGY-HUMAN SECURITY NEXUS: CHALLENGES AND OPPORTUNITIES
}

\begin{abstract}
There is a close relationship between scientific and technological developments and human security issues due to the revolutionary impact of new technologies on different aspects of lives of human beings. However, while modern technology undeniably brings a number of advantages to people, it has also some negative implications for the life of individuals. Therefore, it will be important to examine the bright (opportunity) and dark (challenge) sides of new technologies through the lens of human security due to the ýncreasýng ýmpact of technological developments on security realm and lack of relevant literature. Indeed, there are concerns about security risks stemming from the possible misuse of science and technology. For example, while surveillance technologies lead to personal insecurities, unequal distribution of technology jeopardizes socio-economic problems of people, especially in less-developed parts of the world. Therefore, Janus-faced feature of new technologies should be taken ýnto consýderatýon in order to analyse and comprehend theýr ýmpact on human-beings and their security predicaments.
\end{abstract}

Keywords: human security, technology, surveillance, inequality

\section{Introduction}

When we think about the technology in terms of International Relations discipline, partýcular emphasýs ýs put on the growing effects of technological developments in military affairs and armament efforts of the states (Cohen, 2004). However, it is clear that there is a close relationship between scientific and technological developments and human security issues both in terms of positive and negative aspects. Because, new technologies have a revolutionary impact on different aspects of lives of human beings. On the other hand, when the Security Studies literature is examined, it will be found that there is a huge amount of literature that has been written on peace and human security, human rights and security, environment and 
human security, gender and human security, human security and development, globalisation and human security etc., but there is a small amount of literature on human security and its relationship with scientific and technological developments. However, it is important to determine in which ways new technologies can constitute security problems for human beings.

The waves of technological change have driven economic development and socio-political transformation throughout the history. With the emergence of the fourth industrial revolution, new technologies themselves and their applications are rapidly expanding among people in the world. For example, Microsoft predicts that by $2025,4.7$ billion people will use the Internet - just over half of the world's expected population at that time - and of that number, 75 per cent of users will be in emerging economies (Burt et al., 2014). It is clear that technology has certainly changed the way the world works, influencing almost every aspect of modern social life. But, while modern technology undeniably brings a number of advantages to people, it has also some negative implications for the life of individuals. Indeed, the world has witnessed an increasing confluence of rapidly advancing science and its embodiment in practical technologies, the extensive global diffusion of the knowledge and capabilities associated with those developments. However, the scope and intensity of these interactions have generated concern about security risks stemming from the possible misuse of science and technology (Moodie, 2012). For example, while technological materials and knowledge could lead to the improvements in medicine, agriculture, energy, and other areas that are important for humankind, they can also be exploited for the illicit production of some weapons and goods. Then the question arises how these technologies can be used responsibly to assist those in need, prevent abuse, and protect people from harm. Therefore, it is important to examine the relationships between new technologies and their implications on security needs of human beings.

Technology has always been crucial for the development of effective security policies. However, technological developments have to be reconsidered in a critical manner, as they often give rise to obstacles to fundamental rights and freedoms of human beings. Especially with the rapid increase ýn different surveillance technologies, social impact of technologies has become the subject of an extended political and societal debate. But debates on intersections between science, technology and security need to go beyond the debate on surveillance technologies, as the continuous development of lethal arms as well as the rise of dual-use technologies - technologies that can be used for both civil and military purposes such as drones - 
have changed approaches towards security. Moreover, unequal distribution of technology is another problem, especially for less-developed parts of the world in which significant number of people have difficulties in terms of access to advantages of new technologies. And also, technological developments can generate both positive and negative implications for the life conditions of individuals. Janus-faced feature of new technologies should be regarded in order to analyse and comprehend their effects on human beings and their security predicaments.

\section{Bright and dark sides of technology for human security}

Political science and practical politics are grounded in assumptions about the nature of humans. However, within the discipline of International Relations, there are differing theoretical assumptions about human nature and position of human beings in political life. On the other hand, it is increasingly accepted that individuals and their rights and freedoms have become important subject matters of international relations. Therefore, the emergence of human security concept represents the implication of this process. Although there is a question whether the idea of human security is new or not, in this article, it is argued that it is not a new idea, but it has become immensely popular among scholars, researchers and decision-makers during the last couple of decades.

In spite of some important differences, all theories of social contract argue that a sovereign power has a duty to protect its citizens and they in return have to consent to give it their allegiance and obedience. The social contract emerges among people due to their searches for individual security based on good and safe life. No doubt, there is a close and crucial link between this political contract and the emergence of modern statehood. However, the state's imperative, rather than the individual or collective needs of people, defines security. As a result, state-security paradigm has dominated the security thinking even until present day. Nevertheless, the concept of human security is an ontological challenge to the state security through transforming the state from an end in itself to its original role as a means of security of individuals. Sadako Ogata, the former United Nations High Commissioner for Refugees, has evaluated the state-centric security paradigm in the following way: 'Traditionally, security issues were examined in the context of "state security", i.e. protection of the state, its boundaries, its people, institutions and values from external attacks, and 
that individuals were only to be secured by way of the state' (Ogata, 2015: 26). However, human security is a concept that takes the human - as opposed to the state - as the primary locus of security, and it is concerned with safeguarding and expanding people's vital freedoms. Human security requires both shielding people from acute threats and empowering people to take charge of their own lives (Commission on Human Security, 2003).

Thus, the human security concept has been developed as a response to the dissatisfaction with a perspective of 'security' addressing mainly the state whose security should be protected, with the means of military power capacities and formation of alliances. The 1994 Human Development Report deliberately identified seven areas to broaden the understanding of security: economic security (freedom from poverty), food security (access to food), health security (access to healthcare and protection from disease), environmental security (protection from environmental pollution and depletion), personal security (physical safety that includes freedom from torture, war, criminal attacks, domestic violence, drug use, and suicide), political security (freedom to enjoy civil and political rights, freedom from political oppression) and community security (survival of traditional cultures and identities) (United Nations Development Programme, 1994). With its emphasis on the security of individuals and broadened security agenda, the human security concept has had some success as a normative reference point for human-centred policy movements, and a number of states such as Japan, Norway and Canada and international organizations such as the EU have adopted human security as a policy theme (Newman, 2017: 28).

While human security is subject to conceptual and theoretical debates among scholars of Security Studies, and it has become a policy agenda and guideline for some international actors, the most striking lacking point about it is the effect of new technologies on the life conditions of human beings. Indeed, the problem is that we simply do not know all the positive and negative impacts of new technologies and related developments on human security. In the words of Melvin Kranzberg, 'Technology is neither good, nor bad; nor is it neutral' (Kranzberg, 1986: 547). There are two general statements about the impact of technology on security of individuals. While one statement argues that technology makes people safer, the other one argues that technology makes people more insecure. These two opposing perspectives are subject to continuing debate among scholars, politicians, and practitioners. Accordingly, it will be important to examine the bright (opportunity) and dark (challenge) sides of new technologies through the lens of human security due to the ýncreasýng ýmpact of technological developments on security realm and lack of relevant literature. 


\section{Bright Side}

In 1953, Dwight Eisenhower, the President of the United States of America (USA), made a speech during a meeting of the United Nations (UN) General Assembly, and called for the peaceful usage of atomic energy for the sake of humanity by using the statement of 'Atoms for Peace'. However, researches on atomic energy were transformed into a nuclear armament race between two superpowers, namely the USA and the Union of the Soviet Socialist Republics (USSR) during the Cold War. On the other hand, recent changes and developments in technology have created new opportunities for the areas of sustainable development, governance and state-society relations, peace and conflict, international security, and global governance (Independent Commission on Multilateralism, 2016: 1). Therefore, in this article, 'technology for peace' as a new conceptualization will be introduced in order to identify the bright side of technological developments in terms of human security.

It is worth statýng that human security predicament of the peoples of the world is at greater and greater risk. Indeed, the large majority of them continues to face unacceptable depredation in their access to water, food, health care, resources, and basic security. Therefore, it can be argued that both systemic challenges, such as climate change and war, and more localised threats like social, economic or political disruptions are almost certain. Sustainable solutions, whether at global, regional or country levels, require more advances in scientific knowledge and identification of practical measures for action (Sané, 2008: 34). In this respect, for example, Artificial Intelligence (AI) holds much promise to enable the international community, governments and civil society to predict and prevent human insecurity (Roff, 2017). It is argued that in the coming years AI will be helpful in the domain of human security-related activities in terms of knowledge, planning and empowerment. In addition to acquiring and contextualising knowledge about human security, it is also essential to have the ability to plan the appropriate response for solving them (Roff, 2017).

New technologies have made crucial contributions in terms of increasing awareness of people about their physical, social, economic, political and security environment more quickly than ever before. For instance, mobile phone cameras can easily document and distribute images of physical violence around the world. As another example, drones and satellites can assess disasters from afar. Furthermore, data collected from social media can provide real-time awareness about political protests (Latonero and Gold, 2015). In organisational terms, through some projects, like the Human 
Rights Data Project, data on human rights and human security are generated and analysed by researchers who are creating innovative statistical techniques to document and estimate human rights violations in any part of the world (See: CIRI Human Rights Data Project).

In terms of health security and food security, biotechnology, and more specifically genomics, has an enormous potential to improve current situations in the medium and long term (Dowdeswell et al., 2006). It is projected that the population of the world will reach approximately 8.9 billion in 2050, and therefore, agricultural productivity will have to increase significantly in order to ensure food security of people. In this respect, the potential role of biotechnology in meeting the food needs of the poor people should not be ignored (Dowdeswell et al., 2006: 122-123). In terms of drinkable water needs of people, technological developments can make important contributions by providing better management of water resources, technical advice for better management of groundwater, desalination of seawater and harvesting rainwater.

It is argued that globalisation 'gives more power to individuals to influence both markets and nation-states than at any other time in history' (Friedman, 2002). In this process, current technologies have played an important role in empowering citizens and transforming their relationships with the state due to the globalisation process's emphasis on human rights and humanitarian values. In a digitalised and technologically connected world, information will become an even more powerful tool for development, coordination and, persuasion. In this respect, social media give a new meaning to human rights by promoting access to knowledge, and revealing human rights abuses and violations (Halefom, 2012: 101). Real-time photos and videos uploaded to social media can expose government corruption or abuse and increase government responsiveness to citizen concerns. Under the pressures of information and telecommunication technologies, states are enforced to be more transparent and accountable in their political practices and respectful to human rights by their own citizens. These technologies have also revolutionised people's ability to organise and coordinate protest movements, from the Arab uprisings to protests in Ukraine, to the Occupy Movement (Independent Commission on Multilateralism, 2016: 6). As a specific example, the socio-political activism in Tunisia, known as the 'Jasmine' or 'WikiLeaks revolution' and the Egyptian revolution of 2010-2011, were largely organised, supported and driven through the use of social media-based tools such as Facebook and Twitter. 
According to the World Summit on the Information Society's Tunis Commitment, information and communication technologies can play a role in preventing conflicts through early-warning systems, promoting peaceful conflict resolution, supporting humanitarian action, facilitating peacekeeping missions, and assisting post-conflict peace-building and reconstruction (World Summit on the Information Society, 2005). In 2014 the UN Secretary-General, Ban Ki-Moon mandated a panel of experts to look into the use of technology and innovation in UN peace-keeping missions. In its final report, the panel stated that the availability and effective use of [modern] technology represents the essential foundation to help peace-keeping missions deploy to and manage complex crises that pose a threat to international peace and security' (United Nations Department of Peacekeeping Operations, 2014). The report recommends integrating new technologies into many aspects of peace-keeping operations, including to sustain the basic needs underpinning missions' ability to function, help missions execute their mandates more effectively, and streamline mission support operations (United Nations Department of Peacekeeping Operations, 2014).

\section{Dark Side}

Human security is threatened by disease, hunger, poverty, environmental degradation and physical threats. In the case of each of these threats, technology has a potential to ameliorate the conditions. Although the promise of various biotechnologies, nanotechnology, information technology and others has been widely recognised, through the lens of human security, one can also discern a potential dark side, ways in which the technologies could actually hinder sustainable human development (Dowdeswell et al., 2006: 121) and even jeopardize it. Ulrich Beck argues that modern society has become a risk society in the sense that it is increasingly occupied with debating, preventing and managing risks that it itself has produced (Beck, 1992). In the transition from industrial society to risk society, globalising economy based on scientific and technical knowledge plays a determinant role in the organisation of social relations in which threats to human security are increasingly given attention due to the technological developments.

In order to crystallise the relationship between human security and threats posed by the developments in the information technology, two dimensions of human security, namely freedom from fear and freedom from want, can be taken into consideration. While in terms of freedom from 
fear, threats to human security in the information society can relate to personal security and threats to internet users, violating their civil and political rights, in the context of the freedom from want, threats emanatýng from information technology to internet users affect their economic, social and cultural rights, the rights to education, to health or to development (Benedek, 2012: 3). For instance, even though social media encompass great potential for democratic dialogue, a number of risks and challenges must be identified. Although the Internet is the biggest tool for expression and information-sharing in the world, some racist, nationalist and/or radical groups can find opportunity to increase the number of their followers, and spread their 'hate speeches' to many people by using social media channels. As a reaction, the EU has asked some social media companies such as Twitter, Facebook and Google to outlaw the 'hate speech' contents (European Commission, 2018).

In some cases, personal and political security can be at risk from the potential abuse of information technologies by authoritarian states. For example, in the Syrian conflict, fake Facebook and Twitter login pages were created to capture the personal information of dissidents organising on the Internet. As another example, terrorist groups, such as Al-Qaeda or most recently the Islamic State of Iraq and Syria (ISIS), are masters at using the Internet and communication media to forward their terrorist activities. They establish networks to operate in every corner of the world in order to be able to attract new followers. As another negative implication of new technologies for human security, they make possible new methods of employing lethal force, such as armed unmanned aerial vehicles (UAVs), or drones, that pose new challenges. Their potential use by non-state actors raises further challenges. Moreover, the spread of advanced technology has led to new and grave concerns regarding the proliferation of weapons of mass destruction technologies into irresponsible or unstable hands (Mallik, 2004: 17).

While technological advances have brought new opportunities for political participation and poverty reduction in many regions, disparities of income and inequities are widening and vulnerable groups are being left behind. Indeed, in today's world, 1.2 billion people still live in extreme poverty and face serious deprivations (United Nations General Assembly, 2013). Therefore, one cannot promote human security without promoting socio-economic stability and sustainable human development. To address the issue of human security properly, the economic security should be considered. It is because only a successful industrial development can provide 
a sound base for sustainable growth in incomes and employment opportunities. It is also through industrial development that more skilled jobs are created for the individuals. And it is industry that uses scientific and technological development to the betterment of human-beings in general. Therefore, it can be argued that science leads to technological advances and economic benefits that offer unique opportunities to meet basic human needs, reduce poverty, protect the environment and improve the quality of life (Sané, 2008: 34).

On the other hand, although the use of technologies in human life is increasingly diffused and globalized, technological developments do not affect all persons at once, or to the same degree. In the words of author William Gibson, 'The future is already here - it is just unevenly distributed' (Gibson, 1999). Lester Bowles Pearson, who was the Prime Minister of Canada between 1963-1968, gave attention to the linkages between science and technology, global knowledge inequities and economic development when he asserted that: '...there can be no peace, no security, nothing but ultimate disaster, when a few rich countries with a small minority of the world's people alone have access to the new world of technology, science, and of high material living standards, while the large majority live in deprivation, shut off from opportunities of full economic development' (Dowdeswell et al., 2006: 120).

When we look at the numbers reflectýng the different life conditions of individuals in the world, there are dramatic results. For example, the life expectancy of people in the developed countries such as Canada is about 80 years and rising, while in some countries in sub-Saharan Africa it is less than 40 years and dropping. As another example, one-fifth of the world's people (1.2 billion) experience income poverty and live on less than $\$ 1$ per day; 2.8 billion live in a chronic state of poverty (Dowdeswell et al., 2006: 121-125). Moreover, while 82 percent of people in the developed countries use the Internet, the proportion is just 43 percent globally, 35 percent in the developing countries, 11 percent in Africa, and 9 percent in the leastdeveloped countries (Independent Commission on Multilateralism, 2016: 2). According to the Millennium Development Goals Gap Task Force of the UN, 'as long as more people are offline than online, it is not possible to talk about a global information society' (Millennium Development Goal Gap Task Force, 2015: 68-69). Under these circumstances, it is not easy to expect the realisation of the bright side's effects of technology on the life conditions of the people in the world.

Thus, it is clear that although the potential of new technologies, particularly information and communication technologies (ICTs), to support 
economic development is widely recognised (Independent Commission on Multilateralism, 2016: 2), socio-economic inequalities among people in the world may be worsened by the uneven distribution of technological tools. Consequently, the powerful and wealthy will be the first to have the access to them, and subsequently the gap between the haves and have-nots will be increased. Therefore, as technological sophistication increases, the cost of socio-economic development also rises sharply for the individuals who live in the developing, and especially less-developed countries. In this context, the 2000 UN Millennium Declaration, which laid out goals for a more peaceful, prosperous, and just world, contains a commitment to 'ensure that the benefits of new technologies, especially information and communication technologies,... are available to all' (United Nations Millennium Declaration, 2000).

\section{Surveillance technologies and security of 'other'}

While the UN introduced the concept of 'human security' in the 1990s, the post 9/11 security legislation and security practices represent the returning of state security paradigm, in the name of 'national' security. Indeed, when the current political events are considered, it is clear that there is a correlation between individual insecurities and failure of dominant security thought and its practices. Geopolitical power competitions, interest-based state policies, exclusionary policies towards 'others' and illiberal treatment of refugees and immigrants are trampling on human security. Indeed, at the moment of crisis, policies of national security prevail over the humanitarian needs such as basic freedoms and dignity. Therefore, it may not be an exaggeration to state that the Western societies have transformed their own vision of the 'liberal society', based on democracy, human rights, and tolerant social cooperation, ýnto the vision of an ever-more homogenized society that must protect itself against the 'other' threatening 'their' way of life, potentially making use of 'exceptional means', namely means that do not comply with the rules of democratic states or even given legislation (Haker, 2015).

Pre-emptive security emphasises the necessity of envisioning and designing technologies enabling the anticipation and management of emergent risks threatening human and public security. In this respect, surveillance technologies are implemented to pursue constant monitoring, preparedness and prevention. Yet surveillance-orientated security technolo- 
gies bring along with their implementation other risks, such as risks of privacy infringement, discrimination, misuse or abuse.

As a result of global repercussions of criminal activities, a safer society is often pursued through the implementation of policies foreseen the adoption and deployment of surveillance technologies (Ceyhan, 2002: 102123). More specifically, surveillance technologies aim to collect information about the general population in order to monitor the activities of potential suspects and to prevent criminal and terrorist acts from occurring. However, the introduction of new surveillance measures can be perceived by some people as a threat to their privacy or to their freedom of expression. Therefore, it is argued that a culture of surveillance has emerged that contradicts the vision and values of the human security concept (Haker, 2015).

Surveillance technologies are developed in the area of telecommunication, of ICT-based data generated in almost all everyday life practices (Haker, 2015). In this context, cameras, radio frequency identification, or wireless sensors collect bodily functions such as facial expressions or eye movement, for example at airports or during big public events; biometrical data concerning age, gender, ethnicity, or body weight (Haker, 2015). Thus, technological development certainly radicalises what Foucault called 'biopower': it is not just controlled from a governmental authority but takes on multiple forms, it is embodied by everyone, and all the information cannot be controlled any longer by oversight institutions (Haker, 2015).

\section{Conclusion}

Human security expresses an intention to do more than just treat the symptoms of problems but emphasise the underlying causes and find solutions in the everyday practical experiences of the people who are most at risk and most directly impacted by crises and adverse conditions (Martin, 2017: 16). Therefore, normative content of human security is required to develop implementation tools in order to realise general objectives of human security conception. In other words, in order to empower human security as a concept and policy agenda, it should be operationalised and institutionalised. A far as technology-security nexus is concerned, United Nations Educational, Scientific and Cultural Organization (UNESCO), as the only UN agency, can promote global research, human and institutional capacity-building, networking and policy research through its science programmes (Sané, 2008: 34). However, due to the incapacity and lack of 
resources of individuals, the state should have an ontological obligation to protect its citizens, but also to empower them to protect themselves according to the human security conception. Thus, complementary relationship between state security and human security can be achieved.

In the age of information technology and digitalised world, it is important to assess the risks of emerging new technologies to human security. The risks related with the technological developments can be substantiated through the following examples as decreased security, environmental degradation, hacking and cybercrime, and privacy infringement. If left unregulated, such technologies could lead to serious human security issues. Therefore, there is an urgent need for the regulation of technologies in terms of their repercussions for security of individuals. Besides, humanity needs to be proactive rather than reactive against the risks of technology. Therefore, scholarly studies on human security and its relationships with science and technology will be very important and relevant, and make significant contributions to the literature of human security. In this respect, the key question should be whether or not global community can harness significant technological developments and minimise their risks for the betterment of all.

\section{References}

Beck, U. (1992). Risk Society - Towards a New Modernity. London: Sage Publications. Benedek, W. (2012). Human Security in the Information Age. Human Security Perspectives, 9(1), 1-14.

Burt, D., Kleiner, A., Nicholas, J. P., \& Sullivan, K. (2014). Cyberspace 2025: Today's Decisions, Tomorrow's Terrain. Navigating the Future of Cybersecurity Policy, 6, 47.

Ceyhan, A. (2002). Technologization of Security: Management of Uncertainty and Risk in the Age of Biometrics. Surveillance \& Society, 5(2), 102-123.

CIRI Human Rights Data Project. (2018). Retrieved from http://www.humanrightsdata.com/.

Commission on Human Security. (2003). Human Security Now. New York.

Cohen, E. A. (2004). Change and Transformation in Military Affairs. The Journal of Strategic Studies, 27 (3), 395-407.

Dowdeswell, E., Singer, P. A. and Daar, A. S. (2006). Increasing Human Security through Biotechnology. International Journal of Biotechnology, 8(1-2), 119-131.

European Commission. (2018). Countering Illegal Hate Speech Online, Brussels, 19 January, Retrieved from www.europa.eu/rapid/press-release_IP-18-261_en.pdf.

Friedman, T. L. (2002). Longitudes and Latitudes. Retrieved from http://www.thomaslfriedman.com/longitudesprologue.htm. 
Gibson, W. (1999). The Science of Science Fiction. Talk of the Nation Radio Program, 30 November. Retrieved from www.npr.orgtemplates/story/story. php?storyld=1067220.

Haker, H. (2015). The New Culture of Security and Surveillance. Journal of Political Sciences \& Public Affairs, 3(1), 1-6.

Halefom, M. F. (2012). Human Security and Internet Governance: The Impact of Social Media and ICTs on Conflict Management and Peace Building. Human Security Perspectives, 1, 98-116.

Independent Commission on Multilateralism. (2016). The Impact of New Technologies on Peace, Security and Development, Retrieved from: https://www.icm 2016. org/the-impact-of-new-technologies-on-peace-security-and-development.

Kranzberg, M. (1986). Technology and History: Kranzberg's Laws. Technology and Culture, 27(3), 544-560.

Mallik, A. (2004). Technology and Security in 21 Century: A Demand-side Perspective. SIPRI Research Report, 20, Oxford: Oxford University Press.

Latonero, M. and Gold, Z. (2015). Data, Human Rights \& Human Security. Retrieved from: https://ssrn.com/abstract=2643728.

Martin, M. (2017). Human Security: Present and Future Frontiers. European Journal of Human Security, 1, 9-26.

MDG Gap Task Force. (2015). Taking Stock of the Global Partnership for Development. United Nations, New York, Retrieved from: http://www.un.org/en/development/desa/policy/mdg_gap/mdg_gap2015/2015GAP_FULLREPORT_EN.pdf

Moodie, M. (2012). Book Review: Managing the Security Risks of Emerging Technologies. Arms Control Today, 42(7), 38-42.

Newman, E. (2017). Can Human Security Ideas Ever Be Truly 'Critical'?. European Journal of Human Security, 1, 27-38.

Roff, H. M. (2017). Advancing Human Security through Artificial Intelligence. Research Paper, International Security Department and US and the Americas Programme, Retrieved from: https://www.chathamhouse.org/sites/default/files/publications/research/2017-05-11-ai-human-security-roff.pdf.

Ogata, S. (2015). Striving for Human Security. United Nations Chronical, 52(2), 25-27.

Sané, P. (ed.) (2008). Human Security, Apporaches and Challenges, Paris: UNESCO Publishing.

United Nations Department of Peacekeeping Operations. (2014). Final Report of the Expert Panel on Technology and Innovation in UN Peacekeeping, "Performance Peacekeeping, Retrieved from: http://www.performancepeacekeeping.org/offline/ download.pdf

United Nations Development Programme. (1994). Human Development Report. Oxford: Oxford University Press.

United Nations General Assembly. (2013). Follow-up to General Assembly Resolution 66/290 on Human Security, December 23, Retrieved from: http://www.un.org/en/ ga/president/68/pdf/S-G_Report_on_Human_Security_A-68-685.pdf.

United Nations Millennium Declaration. (2000). UN Doc. A/RES/55/2, September 8, Retrieved from: https://www.preventionweb.net/files/13539_13539ARES552ResolutiononUNMillenniu.pdf. 
World Summit on the Information Society. (2005). Tunis Commitment, UN Doc. WSIS-05/TUNIS/DOC/7-E, November 18, Retrieved from: http://www.itu.int/ net/wsis/docs2/tunis/off/7.html.

\title{
ТЕХНОЛОГИЈА И ЉУДСКА БЕЗБЕДНОСТ: ИЗАЗОВИ И ПРИЛИКЕ
}

\author{
Bülent Sarper AĐIR, ванредни професор \\ Универзитет Аднан Мендерес у Ајдину, Економски факултет у Ајдину
}

\begin{abstract}
Сажетак
Постоји блиска веза између научног и технолошког развоја и питања људске безбедности због револуционарног утицаја нових технологија на различите аспекте живота људи. Међутим, иако модерна технологија несумњиво доноси бројне предности људима, она има и неке негативне импликације за живот појединаца. Стога ће бити важно испитати светле (прилике) и мрачне (изазовне) стране нових технологија кроз сочиво људске безбедности због повећања технолошког развоја у области безбедности и недостатка релевантне литературе. Наиме, постоји забринутост због безбедносних ризика који произлазе из могуће злоупотребе науке и технологије. На пример, док технологије за надзор доводе до личне несигурности, неједнака дистрибуција технологије угрожава друштвено-економске проблеме људи, посебно у мање развијеним деловима света. Због тога би требало искористити Јанус-лице са новим технологијама како би се анализиро и схватио њихов утицај на људска бића и њихове безбедносне неприлике.
\end{abstract}

Кључне речи: људска безбедност, технологија, надзор, неједнакост 